\section{Allelopathic Effect of Glucosinolate- containing Plant Green Manure on Pythium sp. and Total Fungal Population in Soil}

\author{
Luca Lazzeri $^{1}$ and Luisa M. Manici ${ }^{2}$ \\ Istituto Sperimentale per le Colture Industriali, Via di Corticella 133, 40129 \\ Bologna, Italy
}

\author{
Additional index words. biofumigation, Cleome hassleriana, Iberis amara, Rapistrum \\ rugosum, soilborne pathogens
}

\begin{abstract}
Two Brassicaceae (Iberis amara L. selection ISCI14 and Rapistrum rugosum All. selection ISCI4) and a Capparidacea (Cleome hassleriana L. selection ISCI2) possessing glucosinolates whose degradation products exhibit high fungitoxic activity in vitro were assayed as biocidal plants in a green manure simulation. The trials were carried out in pots, using aboveground fresh plant tissues incorporated at a realistic field rate into soil naturally infected by Pythium sp. The effect of these plant tissues on total fungal populations and Pythium sp. were compared with Crambe abyssinica H. cv. Mario, a Brassicacea containing glucosinolates whose degradation products exhibit low fungitoxic activity in vitro, and a plant (Helianthus annuus $\mathbf{L}$.) not containing glucosinolates. All green manure treatments induced increases in total fungi over a 10-week period, showing an enhanced microflora level compared with untreated soil. Pythium sp. was strongly suppressed by the $C$. hassleriana, I. amara, and $R$. rugosum selections, while sunflower and crambe treatments increased Pythium sp. in a manner similar to that observed for total fungal population. These findings indicate that the green manures assayed suppress Pythium sp. and also induced an increase in total soil microbial activity.
\end{abstract}

The production of several vegetable crops depends on the use of methyl bromide (MB) soil fumigation to control a wide array of soilborne fungi, nematodes, insects, and weeds. In accordance with the U.S. Clean Air Act, the use of $\mathrm{MB}$ as a fumigant will be banned in developed nations by 2005 (United Nations Environment Programme, 1992). This decision has prompted increased interest in the development of alternative strategies with a lower environmental impact to control soilborne pathogens.

One alternative approach might be provided by the well-known fungitoxic activity of enzymatic hydrolysis-derived products (DPs) of glucosinolates (GLs), natural compounds of the Brassicaceae (Walker et al., 1937). Their high biological activity has been observed against various fungi using parts of cruciferous plants (Charron and Sams, 1999), crude extracts (Mayton et al., 1996), crucifer-

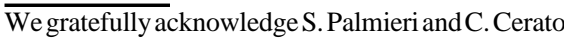
for their helpful discussion. In addition, we thank G. Baruzzi and L. Malaguti very much for their skillful technical assistance. This research was supported in part by the project "Utilizzazione di piante crucifere e di alcuni loro composti secondari ad attività biocida per la lotta a funghi patogeni in piante orticole" financed by the Emilia-Romagna region and in part by the Project POMB30 "Linee innovative di tecnica colturale e difesa a basso impatto ambientale dei fragoleti meridionali.'

${ }^{1}$ Technologist; to whom reprint requests should be addressed. E-mail address: 1.lazzeri@iol.it ${ }^{2}$ Plant Pathologist.
}

ous meal (Smolinska et al., 1997), and also purified GLs hydrolyzed by pure myrosinase (MYR) (Mari et al., 1993). The presence of GLs (Sang et al., 1984) and MYR in Brassicaceae plant organs suggests the possibility of amending soil with fungicidal compounds by using these plants as green manure.

In healthy plants, GLs and MYR are located in different cell compartments and come into contact only after cell collapse, such as occurs following a pathogen attack or when plants are chopped up, with the consequent production of fungicidal GL-DPs (isothiocyanates, thiocyanates, and/or nitriles) in soil. Brassicaceae green manures have been shown to be active against Fusarium oxysporum f.sp.conglutinans (Ramirez-Villapudua and Munnecke, 1988), Verticillium dahliae (Subbarao and Hubbard, 1996), Aphanomyces euteiches (Chan and Close, 1987; Muehlchen et al., 1990), Thielaviopsis basicola (Adams, 1971), Pythium ultimum and Sclerotium rolfsii (Gamliel and Stapleton, 1993), and to strawberry rot root (Lazzeri et al., 1999). Many Brassicaceae used in these studies are commonly available Brassica species, such as cabbage (Brassica oleracea L. var. capitata L.), Indian mustard (B. juncea L.), yellow seed mustard (B. juncea L. ssp.trilocularis Olsson), and rapeseed (B. campestris L.), as well as other common Brassicaceae, like white mus$\operatorname{tard}$ (Sinapis alba L.) and oil radish (Raphanus sativus $\mathrm{L}$.).

Recent studies carried out in vitro with purified GLs and MYR on Fusarium culmorum have shown that the fungicidal activity of DPs varies according to the characteristics of the GL side chain. The DPs from glucoiberin, glucocheirolin, and glucoerucin \{GLs with a extra $\mathrm{S}$ atom in their side chain [thiofunctionalized glucosinolates (GLThio)] \} and from glucocapparin (methyl-glucosinolate) have shown significantly higher fungicidal activity than DPs obtained from aliphatic or hydroxy GLs (Manici et al., 1997). Again in vitro, these GL-DPs showed suppressive activity against some widespread soilborne fungi (Rhizoctonia solani, Pythium sp., and others) (Manici et al., 1999), supporting the hypothesis that these molecules can be used as natural biofumigants. The quality and quantity of GLs in cruciferous plant organs vary according to the genera, species, and, in many cases, the variety (Rosa et al., 1997). Therefore, the biocidal activity of a green manure may vary with the quality and quantity of the GL content of the green manure plant species (Smolinska and Horbowicz, 1999). In recent years, at the Research Institute for Industrial Crops of Bologna, some ecotypes of the Brassicaceae family (Iberis amara L., Rapistrum rugosum All.) and one of the Capparidaceae (Cleome hassleriana L.) were selected for their high content of GL whose DPs have exhibited strong activity in vitro.

The aim of this study was to investigate the allelopathic effect in soil of GL-containing plant green manure. It remains to be clarified as to how much the suppressive effect of cruciferous amendments on soilborne pathogens is due to the fungitoxic effect of GL-DPs (Manici et al., 2000) or the stimulation of microbial activity (Gamliel and Stapleton, 1993; Mazzola, 2000). Therefore, we evaluated variations in Pythium sp. population, a pathogen very sensitive to GL-DPs (Manici et al., 1999), and those of the total fungal population, one of the several components of the soil microbial activity.

\section{Materials and Methods}

In 1997 and 1998, fresh plant tissues of Iberis amara selection sel. ISCI14 (iberis), Rapistrum rugosum sel. ISCI4 (rapistrum), and Cleome hassleriana sel. ISCI2 (cleome), with a high content of strongly active GL-DPs, were incorporated into a naturally infested soil in pots. Crambe abyssinica H. cv. Mario (crambe), a species containing GLs producing low fungitoxic DPs, and Helianthus annuus L. cv. Gloriasol (sunflower), a plant that does not contain GLs, were inserted in the experiments as nonbiocidal green manure controls.

Green manure crop production. In both years, the green manure crops were cultivated in the Po Valley (Budrio, Bologna, Italy; continental climate), in plots $\left(15 \mathrm{~m}^{2}\right)$ arranged in a randomized block design, with three replicates. The trials were performed on a silt loam soil (clay 26\%, silt 54\%, sand 20\%) with a high content in available potassium (240 ppm) and average content in phosphate (35 ppm) and organic matter $(1.8 \%)$. At sowing time, 80 $\mathrm{kg} \cdot \mathrm{ha}^{-1}$ of $\mathrm{N}$ (ammonium nitrate) and 100 $\mathrm{kg} \cdot \mathrm{ha}^{-1}$ of sulfur were applied. Biocidal plants were sown in the first week of March, with a 
density of $\approx 250$ seeds $/ \mathrm{m}^{2}$, in rows $28 \mathrm{~cm}$ wide for rapistrum and crambe and $14 \mathrm{~cm}$ wide for iberis and cleome. During cultivation, no irrigation water and pesticide treatments were applied. At full flowering, the fresh biomass yield $\left(\mathrm{t} \cdot \mathrm{ha}^{-1}\right)$ of aboveground parts was evaluated and the dry matter (DM) content (\%) was measured by oven-drying a plant sample at $105{ }^{\circ} \mathrm{C}$ overnight.

Glucosinolate and myrosinase determination. At full flowering, a sample of each GLcontaining plant was weighed, immediately frozen at $-20{ }^{\circ} \mathrm{C}$, and subsequently freezedried using an Edwards Minifast Do.1 freezedrier (from -40 to $+18^{\circ} \mathrm{C}$ in $8 \mathrm{~h}$ with a vacuum of $10^{-1} \mathrm{mbar}$ ). The freeze-dried materials were then homogenized with a mortar and their GL content was determined following the procedure proposed for rapeseed analysis in the Official Journal of the European Community (1990), with some minor modifications (Visentin et al., 1992). A Hewlett Packard high-pressure liquid chromatograph (HPLC) model $1090 \mathrm{~L}$, equipped with a diode array detector and a $200 \times 4.6 \mathrm{~mm} 5-\mu \mathrm{m}$ column HP ODS Hypersil C18, was used. A $\mathrm{CH}_{3} \mathrm{CN}: \mathrm{H}_{2} \mathrm{O}$ (1:22) gradient was used at the flow of 2 $\mathrm{mL} \cdot \mathrm{min}^{-1}$.

To confirm the presence of MYR in plant organs, the freeze-dried tissues were homogenized in water $(1: 2)$ with an Ultra-Turrax TP18/2K Ika Werk Staufen, Germany, in screw-capped vials and incubated in a water bath at $37^{\circ} \mathrm{C}$ for $12 \mathrm{~h}$. The mixtures were then filtered through paper (Whatman 1, England) and the GL-DPs were extracted with $\mathrm{CH}_{2} \mathrm{Cl}_{2}$ (four extractions). The extracts were dried adding anhydrous $\mathrm{Na}_{2} \mathrm{SO}_{4}$, filtered on paper, concentrated under $\mathrm{N}_{2}$ stream, and finally analyzed in GC-MS with a GCD Hewlett Packard model G1800A equipped with a $30 \mathrm{~m} \times 0.25$ mm capillary column HP- $5 \mathrm{MS}$. The flow rate of the carrier gas (He) was $1 \mathrm{~mL} \cdot \mathrm{min}^{-1}$ and the sample $(1 \mu \mathrm{L})$ was injected in the splitless mode. Column temperature was $40{ }^{\circ} \mathrm{C}$ at the start and $220^{\circ} \mathrm{C}$ at the end of the analysis, with a rate of $10^{\circ} \mathrm{C} \cdot \mathrm{min}^{-1}$. The injector and detector temperature were $260^{\circ} \mathrm{C}$. Ionization energy was $70 \mathrm{~W}$ and mass spectra were scanned in the $10-425 \mathrm{~m} / \mathrm{z}$ range. Peaks of GL-DPs were identified using the NBS75K library.

Green manure simulation. Trials were carried out using a silty clay loam soil (39\% clay, $49 \%$ silt, $12 \%$ sand), series Medicina, fine, mixed, mesic Vertic Ustochrepts (Soil Taxonomy, 1994), naturally infested with Pythium sp., collected in May 1997 and 1998 in Cesena (eastern Po Valley) from nonfumigated fields, which had been cultivated with strawberry for several years. The field was fallow in 1997. In autumn 1997, burley green manure was planted, followed by strawberry in summer 1998. Soil (pH 8.2) was collected at random from the top $20 \mathrm{~cm}$, partially dried at room temperature for $3 \mathrm{~d}$, and then stored at 8 to $10^{\circ} \mathrm{C}$ for $4 \mathrm{~d}$. Before treatment, soil was sieved through a $5-\mathrm{mm}$ mesh screen and homogenized by hand.

Intact aboveground plant tissues were collected at full flowering time, chopped in a razor blender, and immediately incorporated into the soil. Roots were not included, due to difficulty in obtaining complete grinding during plant chopping, which could result in lower GL-DP yields. Plant biomass was applied using a realistic field rate, which was based on the biomass obtained in the field during 1997 (Table 1), without considering roots. Sunflower and crambe, also collected at full flowering stage, were incorporated into the soil at the highest biomass application employed for biocidal selections (Table 1). For each treatment, $4 \mathrm{~kg}$ of soil were amended with four doses of fresh, chopped plant tissue. Soil and plant tissue were mixed by hand and then arranged in four pots to create a soil layer of 13 $\mathrm{cm}$ and an area of $\approx 140 \mathrm{~cm}^{2}$. Untreated soil was also included in the experiments. After plant tissue incorporation, $120 \mathrm{~mL}$ of water was added to each pot, to generate a final moisture content of $\approx 25 \%$ (approximating field capacity). Pots were stored in the greenhouse at 26 to $28^{\circ} \mathrm{C}$ and watered once a week. The experiments were arranged in a randomized complete-block design with four replicates.

Pythium sp. and total fungal population evaluation. Pythium sp. and total fungal popu- lations were recorded 3,6 , and 10 weeks after plant incorporation. Twenty-five-gram soil samples were collected from each pot and mixed with $225 \mathrm{~mL}$ of sterile water with a magnetic stirrer for $10 \mathrm{~min}$ to obtain a $10^{-1}$ diluted soil solution, and analyzed by the soil dilution plate method on selective media (Dhiangra and Sinclair, 1986).

Pythium sp. Three plates of selective media were spread with $0.5 \mathrm{~mL}$ of $10^{-1}$ and $10^{-2}$ soil dilutions according to the modified Jeffers and Martin (1986) method (cornmeal amended with $5 \mathrm{mg} \cdot \mathrm{L}^{-1}$ Pimaricin, $250 \mathrm{mg} \cdot \mathrm{L}^{-1}$ Ampicillin, $10 \mathrm{mg}$ Rifampicin, $100 \mathrm{mg}$ of PCNB, and 1 $\mathrm{g} \cdot \mathrm{L}^{-1} \mathrm{Ox}$-gall). After an incubation time of 24 $\mathrm{h}$ at $18{ }^{\circ} \mathrm{C}$ in the dark, the soil dilution was washed from plate surfaces under running water, and then Pythium colonies were counted. To record the relative Pythium sp. frequency, all germinating propagules with typical Pythium morphology on PARP $+\mathrm{Ox}$-gall were transferred on PDA $+200 \mathrm{mg} \cdot \mathrm{L}^{-1}$ streptomycin sulfate. Pythium colonies with common macroscopic and microscopic characters were clustered; the representative isolates of each cluster were identified on the basis of the Waterhouse key (1967) and description (1968). Pythium identification was performed, in one case (Pythium deliense Meurs), and confirmed, in another case (Pythium ultimum Trow. var. ultimum), by the Centraalbureau voor Schimmelcultures (Baarn, The Netherlands). Pythium inoculum was reported as colony forming units per gram $\left(\mathrm{CFU} \cdot \mathrm{g}^{-1}\right)$ of air-dried soil.

Total fungal population: One milliliter of $10^{-2}$ and $10^{-3}$ soil dilutions was mixed with 49 $\mathrm{mL}$ of water agar $+3 \mathrm{~g} \cdot \mathrm{L}^{-1} \mathrm{Ox}$-gall and 200 $\mathrm{mg} \cdot \mathrm{L}^{-1}$ streptomycin sulfate, distributed on five (9-cm diameter) petri dishes, and incubated for $48 \mathrm{~h}$ at $24 \pm 2{ }^{\circ} \mathrm{C}$ under natural light. Colonies were counted by visual observation and expressed as CFU.g ${ }^{-1}$ air-dried soil. Fungal isolates with different morphologies were transferred to PDA $+200 \mathrm{mg} \cdot \mathrm{L}^{-1}$ streptomycin sulfate. Colonies were identified on the basis of macroscopic and microscopic morphological characteristics using the relevant taxo-

Table 1. Glucosinolate content of fresh matter of biocidal selections used in green manure simulation.

\begin{tabular}{|c|c|c|c|c|c|c|}
\hline \multirow[b]{3}{*}{$\underline{\text { Biocidal selections }}$} & \multicolumn{2}{|c|}{ Glucosinolates } & \multirow{2}{*}{\multicolumn{2}{|c|}{$\begin{array}{c}\text { Biomass } \\
\text { incorporated } \\
\text { into the soil } \\
\left(\mathrm{g} \cdot \mathrm{kg}^{-1} \text { of soil }\right) \\
\end{array}$}} & \multirow{2}{*}{\multicolumn{2}{|c|}{ Glucosinolates added to soil }} \\
\hline & \multirow{2}{*}{$\begin{array}{c}\text { Content } \\
\left(\mu \mathrm{mol} \cdot \mathrm{g}^{-1} \text { of } \mathrm{FM}\right)\end{array}$} & \multirow[b]{2}{*}{ Main $^{z}$} & & & & \\
\hline & & & $\mathrm{FM}^{\mathrm{y}}$ & $\mathrm{DM}^{\mathrm{x}}$ & $\left(\mathrm{mmol} \cdot \mathrm{kg}^{-1}\right.$ of soil $)$ & $\left(\mathrm{mg} \cdot \mathrm{kg}^{-1}\right.$ of soil $)$ \\
\hline 1997 & & & & & & \\
\hline Iberis amara ISCI14 & $4.5 \pm 0.4^{\mathrm{w}}$ & IBE $98 \%$ & 40 & 7.4 & $0.18 \pm 0.02$ & $83 \pm 8$ \\
\hline Rapistrum rugosum ISCI4 & $6.1 \pm 0.4$ & GCH 95\% & 60 & 11.1 & $0.37 \pm 0.02$ & $173 \pm 10$ \\
\hline Crambe abyssinica $\mathrm{cv}$. Mario & $4.1 \pm 0.4$ & E-PRO 90\% & 60 & 15.1 & $0.24 \pm 0.03$ & $103 \pm 12$ \\
\hline Cleome hassleriana ISCI2 & $5.4 \pm 0.8$ & GCA $90 \%$ & 40 & 8.0 & $0.22 \pm 0.04$ & $79 \pm 13$ \\
\hline Helianthus annuus L. & Absent & --- & 60 & 10.8 & --- & --- \\
\hline 1998 & & & & & & \\
\hline Iberis amara ISCI14 & $4.5 \pm 0.4$ & IBE $98 \%$ & 40 & 6.8 & $0.18 \pm 0.02$ & $83 \pm 8$ \\
\hline Rapistrum rugosum ISCI4 & $6.2 \pm 0.4$ & GCH 95\% & 60 & 11.7 & $0.37 \pm 0.02$ & $173 \pm 13$ \\
\hline Crambe abyssinica $\mathrm{cv}$. Mario & $7.0 \pm 0.5$ & E-PRO $85 \%$ & 60 & 14.8 & $0.42 \pm 0.03$ & $179 \pm 12$ \\
\hline Cleome hassleriana ISCI2 & $8.9 \pm 0.6$ & GCA $81 \%$ & 40 & 8.5 & $0.35 \pm 0.03$ & $131 \pm 10$ \\
\hline Helianthus annuus L. & Absent & --- & 60 & 10.6 & --- & --- \\
\hline
\end{tabular}

${ }^{2} \mathrm{IBE}=$ Glucoiberin; GCH = Glucocheirolin; E-PRO = Epi-progoitrin; GCA = Glucocapparin .

yFresh matter.

Dry matter.

wMean \pm SD. 
nomic keys (Nelson et al., 1983; Samson and van Reenen-Hoekstra, 1988; Sutton, 1980). Total fungal population was reported as CFU.g ${ }^{-1}$ of air-dried soil.

Statistical analysis. Data were subjected to one-way analysis of variance and to mean separation by least significant differences (LSD) test at $P \leq 0.05$ significance level, using the Statgraphic Plus Program, version 2 (Manugistatic, Rockville, Md.).

\section{Results}

Agro-technological plantcharacterization. All plant selections showed good adaptation to spring sowing in the Po Valley pedoclimatic conditions, with sufficient vegetative growth and abundant flowering. The cycle length from sowing to full flowering varied from 78 to 85 d in 1997 and from 95 to $99 \mathrm{~d}$ in 1998 .

In 1997, at full flowering the biomass yield of aboveground parts alone was $2.7 \pm 0.3$ $\mathrm{kg} \cdot \mathrm{m}^{-2}$ fresh matter (FM) for iberis and cleome and $4.2 \pm 0.9 \mathrm{~kg} \cdot \mathrm{m}^{-2} \mathrm{FM}$ for rapistrum (Table 1). On the basis of these data and with the aim of reproducing in pots the field green manure conditions, the plant biomass incorporated into pots in the two trial years was $40 \mathrm{~g} \cdot \mathrm{kg}^{-1}$ of soil for iberis and cleome and $60 \mathrm{~g} \cdot \mathrm{kg}^{-1}$ of soil for rapistrum, crambe, and sunflower (Table 1). The aboveground tissues of iberis and rapistrum in both years contained, respectively, $4.5 \mu \mathrm{mol} \cdot \mathrm{g}^{-1} \mathrm{FM}$ of glucoiberin (3methylsulfinylpropyl-glucosinolate) and $>6.1 \mu \mathrm{mol} \cdot \mathrm{g}^{-1} \mathrm{FM}$ of glucocheirolin (3methylsulfonylpropyl-glucosinolate). The GL content of crambe and cleome varied from year to year. Crambe GL content was 4.1 in 1997 and $7.0 \mu \mathrm{mol} \cdot \mathrm{g}^{-1} \mathrm{FM}$ in 1998 . In both years, it included $\approx 85 \%$ of Epi-progoitrin (2hydroxybut-3-enyl-glucosinolate) and $15 \%$ of gluconapin (but-3-enyl-glucosinolate). Cleome GLs content was 5.4 in 1997 and $8.9 \mu \mathrm{mol} \cdot \mathrm{g}^{-1}$ FM in 1998. In both years, it contained $\approx 85 \%$ glucocapparin (methyl-glucosinolate) and $15 \%$ glucocleomin (2-hydroxy-2-methylbutylglucosinolate) (Table 1).

Endogenous MYR was able to completely hydrolyze GLs, as confirmed by the complete absence of GLs in plant-extracts homogenized for $12 \mathrm{~h}$ in a water bath at $37{ }^{\circ} \mathrm{C}$ (data not shown). Iberis and rapistrum GLs produced primarily the corresponding isothiocyanate while crambe tissues produced primarily vinyl-oxazolidine-2-thione. Cleome produced a mixture of methyl-isothiocyanate and 5-methyl-5-ethyl-oxazolidine-thione.

Effect of green manure on total fungal population. In the two trial years, all five fresh tissue treatments increased the total fungal population in amended soil, compared with untreated soil.

In 1997, total fungal population in the untreated soil did not vary significantly from the first $\left(17,900 \mathrm{CFU} \cdot \mathrm{g}^{-1}\right.$ dry soil) to the last sampling time $\left(22,720 \mathrm{CFU} \cdot \mathrm{g}^{-1}\right.$ dry soil) (Fig. $1 \mathrm{~A}$ and $\mathrm{C}$ ), while, as expected, all five green manure treatments significantly increased total fungal population. Three weeks after green manuring, iberis, rapistrum, and cleome generated a significantly higher fungal population
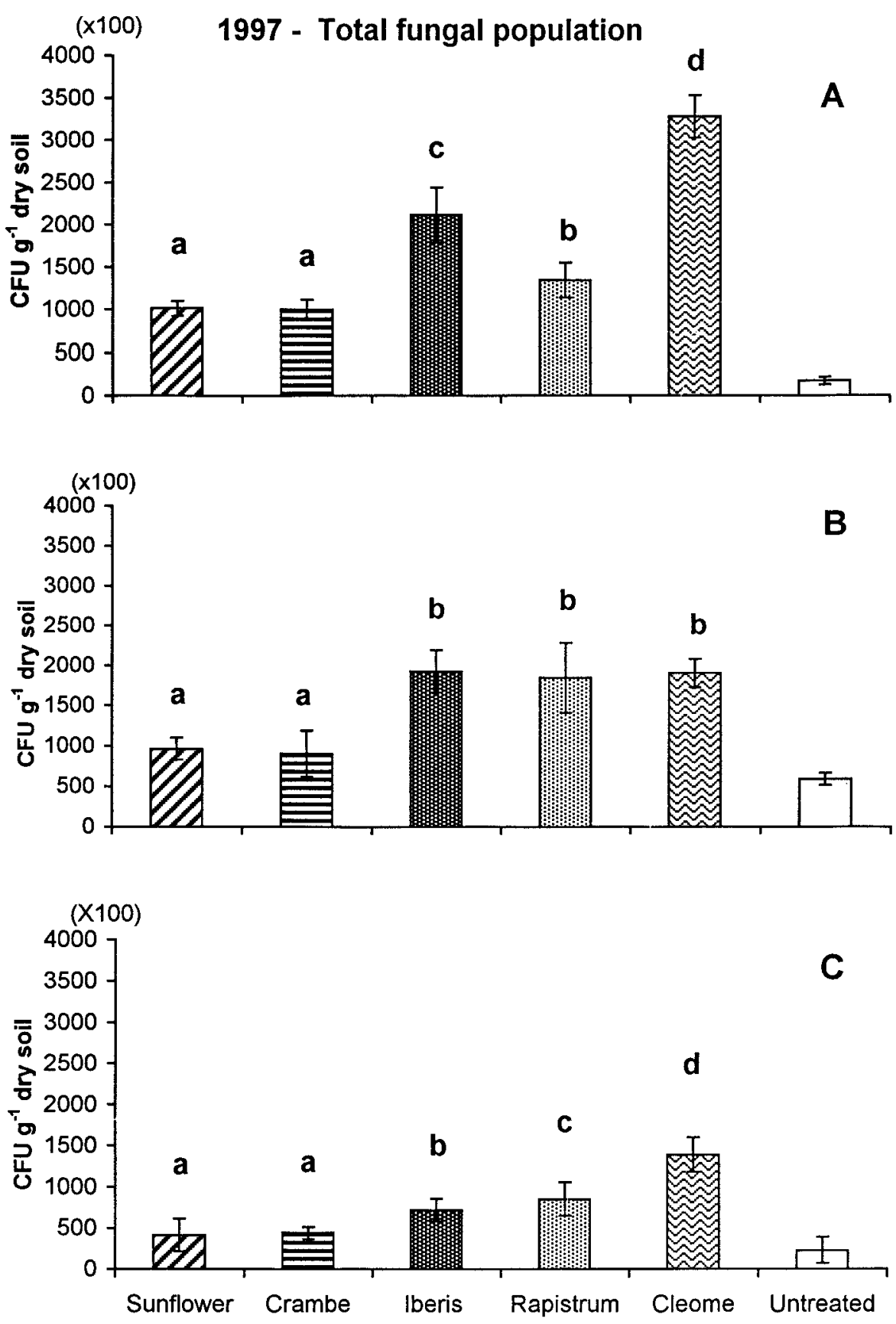

Fig 1. Total fungal population in soil, (A) 3, (B) 6, and (C) 10 weeks after green manure amendment (1997). Bars indicate standard error. Treatment means with the same letter are not significantly different as determined by LSD method $(P \leq 0.05)$.

than sunflower and crambe (Fig. 1A). After 6 weeks, the total fungal population after iberis, rapistrum, and cleome treatments was very similar, maintaining values significantly higher than crambe and sunflower treatments (Fig. 1B). After 10 weeks, cleome generated the highest value, followed by rapistrum and iberis, while sunflower and crambe generated a significantly lower value (Fig. 1C). Even at this last sampling time, all green manure treatments increased total fungal population from $200 \%$ (sunflower and crambe) to $600 \%$ (cleome), compared with untreated soil.

In 1998, the total fungal population in untreated soil was higher than in 1997 and decreased strongly from the first $(90,000$
$\mathrm{CFU} \cdot \mathrm{g}^{-1}$ dry soil $)$ to last sampling time $(21,000$ CFU. ${ }^{-1}$ of dry soil) (Fig. 2 A and C), reaching the level observed in the previous year after 10 weeks. Three weeks after green manure treatments (Fig. 2A), total fungal population in the cleome treatment had increased to levels significantly higher than the other treatments, which, compared with untreated soil, had $>200 \%$. After 6 weeks, the fungal population remained $>100,000 \mathrm{CFU} \cdot \mathrm{g}^{-1}$ dry soil with no differences among the treatments (Fig. 2B). After 10 weeks, crambe and cleome showed a total fungal population significantly higher than iberis and sunflower, although this was not significantly different from rapistrum treatment (Fig. 2C). Even at the last sampling time, 
all green manure treatments, compared with untreated soil, increased total fungal population by $200 \%$ (iberis) to $300 \%$ (cleome).

In both trial years, $60 \%$ to $80 \%$ of fungi recovered from soil were Fusarium oxysporum Schlect. emend Snyd. \& Hans., Fusarium solani (Mart.), Fusarium equiseti (Corda) Sacc., Myrothecium verrucaria (Albert. \& Schwei.: Fries) Ditmar, Mucor hiemalis Wehmer, Staphylotrichum coccosporum J.A. Mayer \& Nicot. In addition, a small number of the genera Aphanomyces, Aspergillus, Mortierella, Pestalotia, Rhizopus, Trichoderma, and a sterile fungus were detected.

Effect of green manure on Pythium sp. In untreated soil, the Pythium sp. population gradually decreased in both trial years: in 1997 from a starting level of 305 to $22 \mathrm{CFU} \cdot \mathrm{g}^{-1}$ dry soil after 10 weeks (Fig. $3 \mathrm{~A}$ and C), and in 1998 from 238 to 48 CFU.g ${ }^{-1}$ dry soil (Fig. 4 A and $\mathrm{C}$ ).

In 1997, at all sampling times, the Pythium population with sunflower soil treatment was higher than with all other soil treatments. Even crambe induced a strong increase in the Pythium population, but significantly lower than sunflower, whereas cleome, iberis, and rapistrum strongly suppressed Pythium sp. (Fig. 3A-C). In detail, 3 weeks after green manure, sunflower and crambe increased Pythium to 2200 and $1800 \mathrm{CFU} \cdot \mathrm{g}^{-1}$ dry soil, respectively, while the three biocidal plant selections, cleome in particular, reduced Pythium population to a level lower than that of untreated soil. Six weeks after green manure, sunflower and crambe treatments showed an unchanged inoculum level as compared with the first sampling time. Iberis and cleome suppressed Pythium population at a level significantly lower than rapistrum, which, however, maintained Pythium population at $\approx 600 \mathrm{CFU} \cdot \mathrm{g}^{-1}$ dry soil (Fig. 3B). Ten weeks after green manure, Pythium decreased strongly with all treatments even if there was still a significantly higher inoculum level with sunflower and crambe. Crambe was not statistically different from rapistrum, while iberis and cleome were again the most effective, suppressing Pythium to values $<40 \mathrm{CFU} \cdot \mathrm{g}^{-1}$ dry soil (Fig. 3C).

Even in 1998, at all sampling times, sunflower and crambe increased the Pythium population to levels significantly higher than the three biocidal selections (Fig. 4A-C). Three and 6 weeks after green manure, in fact, sunflower and crambe increased Pythium population to values $\approx 3000 \mathrm{CFU} \cdot \mathrm{g}^{-1}$ dry soil without significant differences. As in 1997, iberis, rapistrum, and cleome decreased Pythium populations to levels lower or similar to that of untreated soil, showing no significant differences among them at three subsequent sampling times (Fig. 4A-C). After 10 weeks, the inoculum decrease with sunflower and crambe treatments was not as strong as in the first year.

The Pythium population was represented by two main clusters, one $P$. deliense and the other P. ultimum var. ultimum. Those two phytopathogenic species were the only ones isolated from soil samples in this 2-year trial.
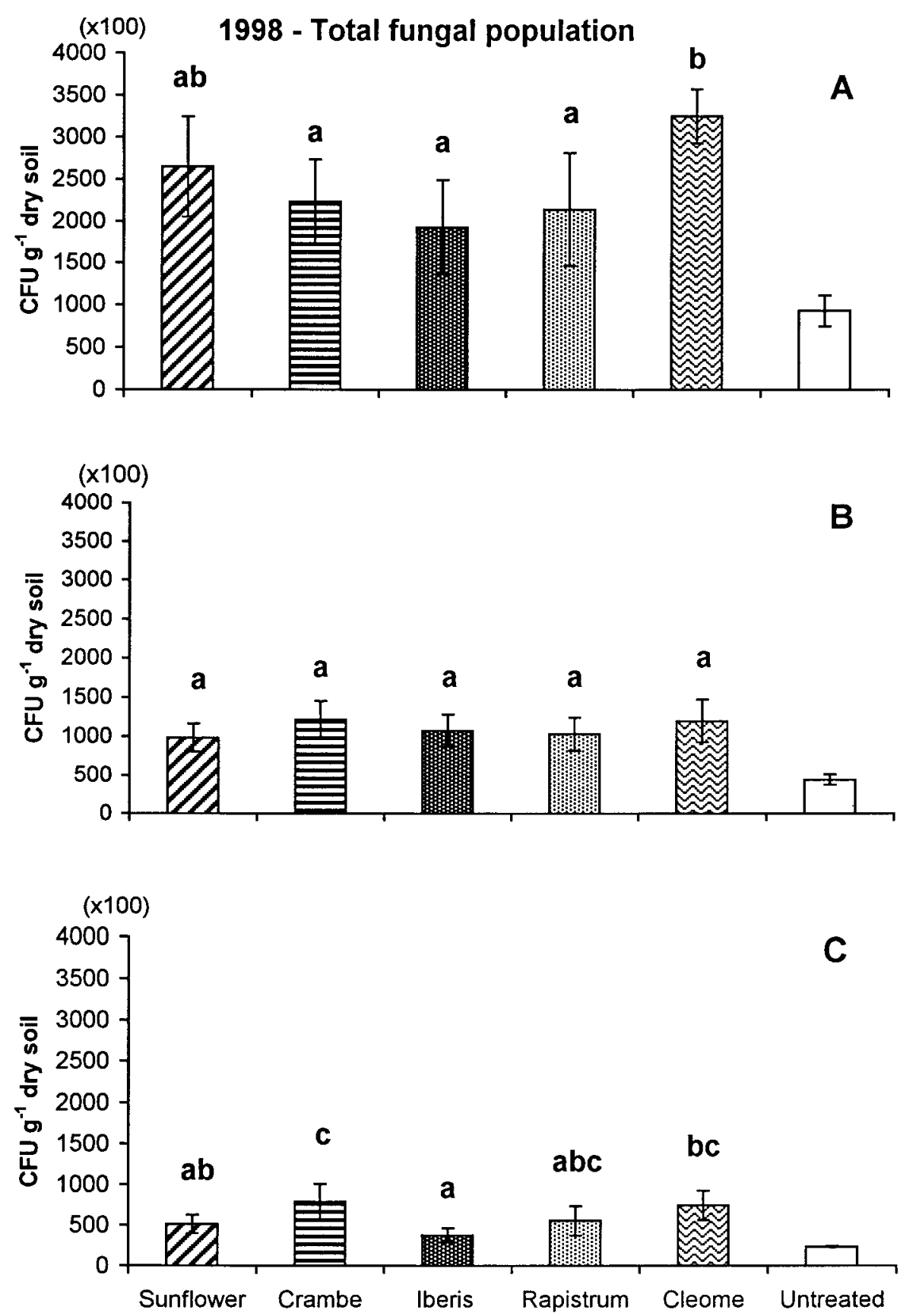

Fig 2. Total fungal population in soil, (A) 3, (B) 6, and (C) 10 weeks after the green manure amendment (1998). Bars indicate standard error. Treatment means with the same letter are not significantly different as determined by LSD method $(P \leq 0.05)$.

\section{Discussion}

In recent years, interest has increased in the use of cover crops to control soilborne pathogens (Elmer and LaMondia, 1999; Grünwald et al., 2000), even though many authors (Stanghellini and Hancock, 1971) have observed a significant increase of Pythium sp. in soil amended with fresh plant tissues. Pythium root rot damage is often associated with soil management practices that increase crop residues in soil, such as direct drilling or green manure (Cook et al., 1980; Davis and Nunez, 1999). On the other hand, a wellknown biological effect of amending soil with fresh plant tissues is the rapid increase in soil microbial biomass (Ploetz et al., 1985), of which fungi are commonly the largest component (Anderson and Domsch, 1975), and represent an important soil fertility parameter (Lynch and Panting, 1980).

In this study, two phytopathogenic Pythium species, $P$. ultimum and $P$. deliense, were isolated from amended and nonamended soil samples. Pythium ultimum, one of the most widespread agents of damping-off and root rot in annual and perennial crops, has also been reported to be an agent of strawberry black root rot (Watanabe et al., 1977). Pythium deliense is a less common Pythium species and is reported as an agent of damping-off of tomato seedling and many other crops 

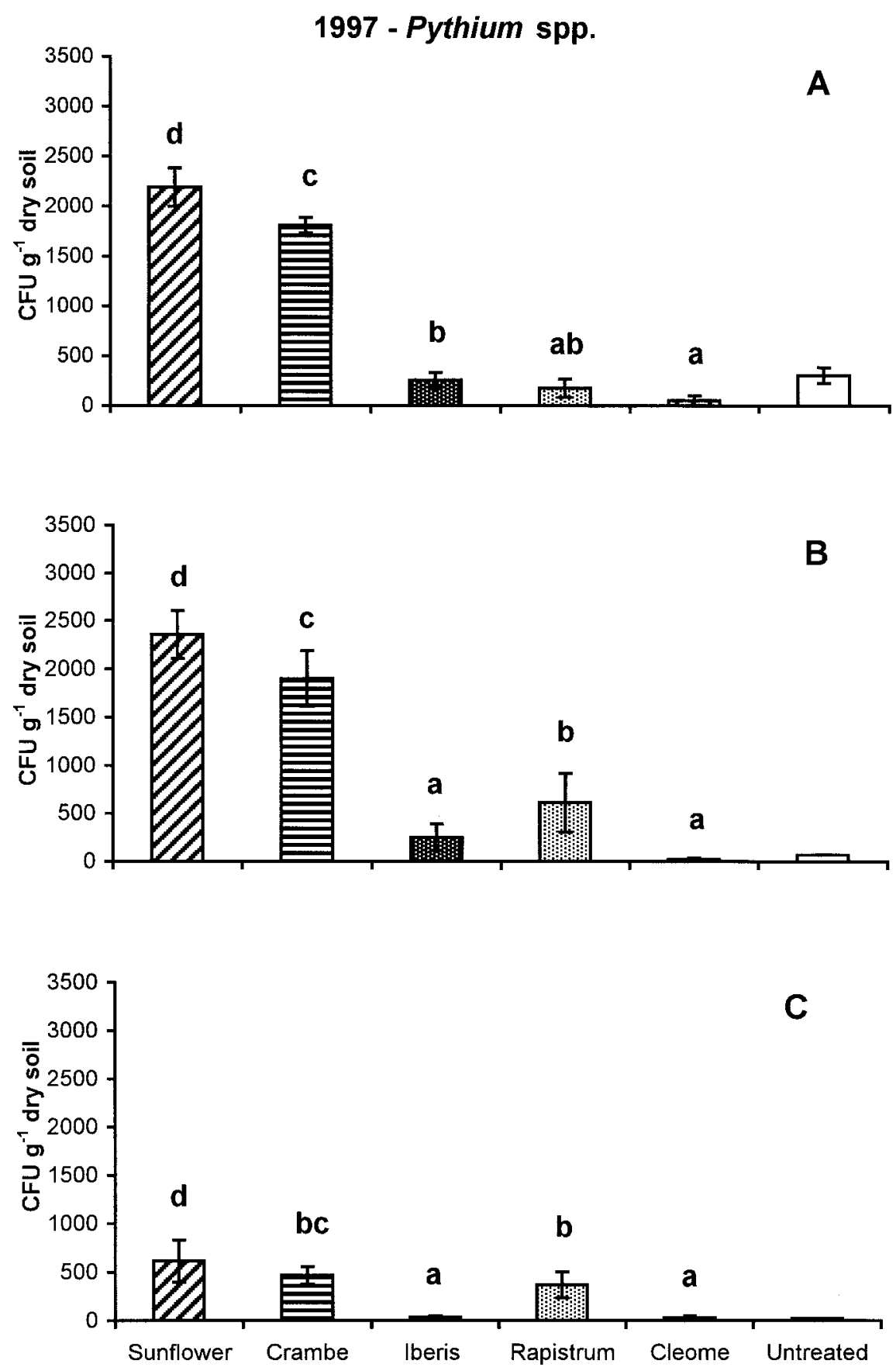

Fig. 3. Pythium sp. population in soil, (A) 3, (B) 6, and (C) 10 weeks after the green manure amendment (1997). Bars indicate standard error. Treatment means with the same letter are not significantly different as determined by LSD method $(P \leq 0.05)$.

(Waterhouse and Waterston, 1966). Therefore, the highly pathogenic Pythium sp. population in the soil used in this study provided ideal conditions for evaluating the fungitoxic effect of compounds released by GL-containing plants on the pathogen (Manici et al., 2000) in field soil.

Sunflower green manure, included in the trials as a plant that does not contain GLs, confirmed the effects reported above, strongly enhancing both total fungal and Pythium sp. populations. Crambe green manure had a similar effect even though it provided soil with a good level of GLs (Epi-progoitrin), especially in 1998. Crambe GL-DPs (primarily vinyl-2oxazolidine-thione) are characterized by low opment was mainly affected by the addition of fresh organic matter and not limited by GL-DP biocidal activity (Figs. 1 and 2).

The total soil fungal population strongly increased from 3 to 10 weeks after treatments, confirming the rapid response of pathogenic and nonpathogenic saprophytic fungi to the availability of a fresh organic substrate. At the same time, the suppression of Pythium by the ISCI biocidal selections was clearly evident. This effect was probably due to GL-DPs released during plant chopping, whose fungitoxic effect widely overcame the stimulant effect of organic matter amendment. The increase in total fungal population and contemporary decrease in Pythium, observed with GL containing plant treatments, may be due to the high sensitivity of Pythium to GL-DPs and to the low sensitivity of Deuteromycetes, the most common of the fungi recovered (Manici et al., 1997, 1999).

Crambe green manure clearly increased the Pythium population in a manner similar to that of sunflower. This suggests that plants containing GLs producing DPs with low fungitoxic activity can generate an increase in Pythium populations similar to that of conventional green manure. On the contrary, the ISCI selections reduced Pythium to values lower than untreated soil, with a clear fungitoxic effect, confirming that the biofumigant effect in soil depends not only on the amount of GLs, but above all on the fungitoxicity of their DPs.

This study in potted, naturally infected soil was planned to simulate green manure in the open field, even if the controlled laboratory conditions probably improved both the fresh plant tissue biofumigant effect and the organic matter decomposition process. Fresh tissues were in fact incorporated into the soil in a partially closed system (pots) that, probably, reduced the GL-DPs loss compared with the open field. Furthermore, the fine plant tissue grinding and the soil watering generated a rapid GLs hydrolysis, improving the fungitoxic effect of biocidal green manure, enhancing the response of Pythium and total fungi to fresh biomass addition. Therefore, the changes in Pythium sp. and total fungal populations in our experiments were probably faster than in the field conditions. In addition, the silty clay loam soil from east Po valley, a vegetablegrowing area of northern Italy, was probably aerated more in pots than under field conditions, thus further enhancing fresh biomass decomposition. For this reason, in soils with a similar texture, green manure of plants selected for GLs content may be useful in low input or organic farming horticulture, where green manures are commonly adopted. In fact, the suppression of the Pythium population in soil observed during the first weeks after fresh tissue incorporation into the soil, could prevent the rapid increase of Pythium, thus reducing the period in which this pathogen can cause damping-off or root rot of seedlings and young plants.

Pythium survives as a saprophyte in competition with other microorganisms (Chen et al., 1988) and so the strong increase in soil fungal populations may represent an addi- 

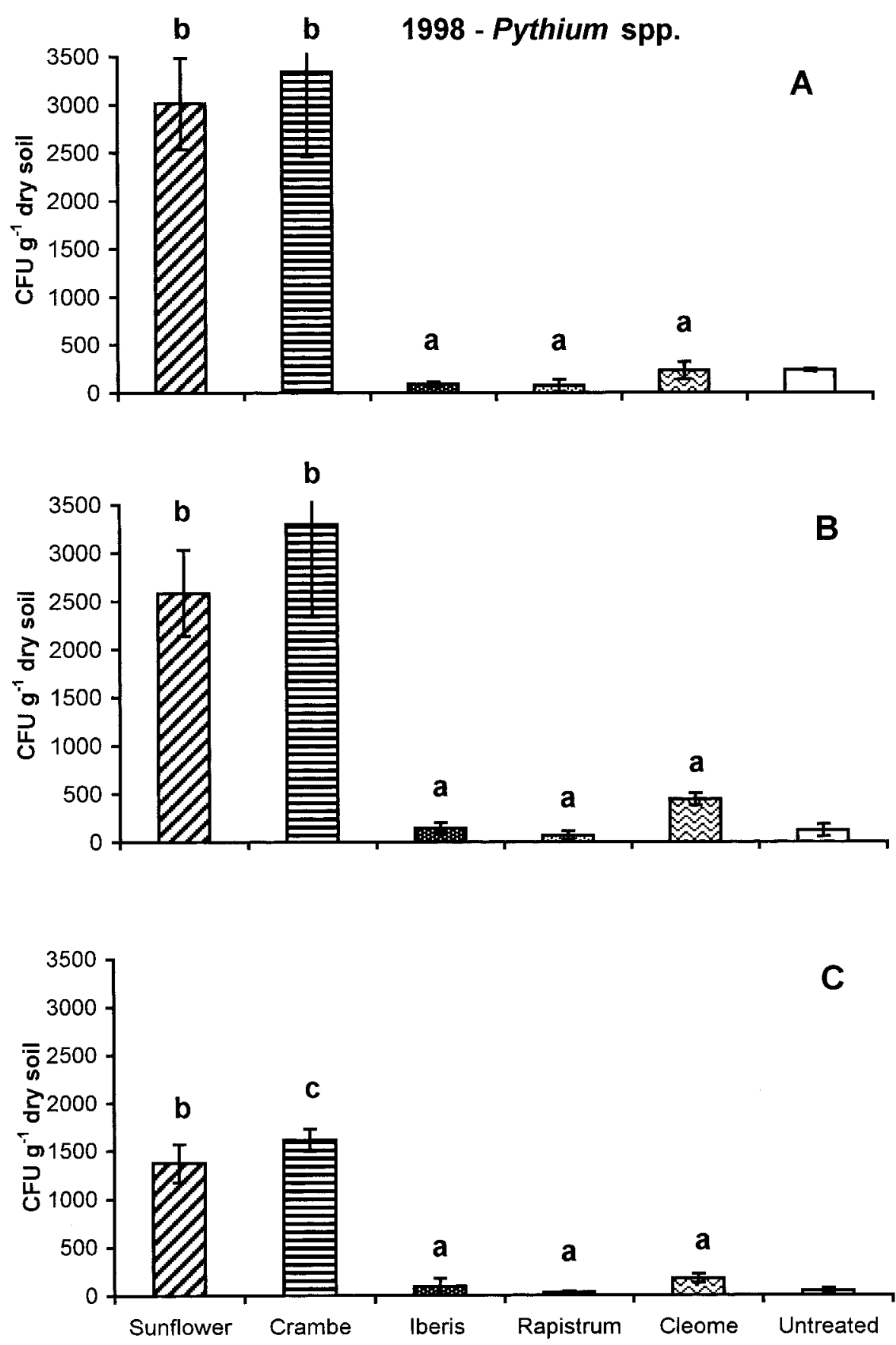

Fig 4. Pythium sp. population in soil, (A) 3, (B) 6, and (C) 10 weeks after the green manure simulation (1998). Bars indicate standard error. Treatment means with the same letter are not significantly different as determined by LSD method $(P \leq 0.05)$.

tional suppressive effect of GL containingplants. The increase in the total fungal population and the suppression of Pythium sp. observed with selected GL-containing plant green manure might be interesting for application in soils cultivated with the same crop for several years where there can be an increase in Pythium sp. pathogenic to the crop (Mazzola, 1998). In this case, the reduction of pathogenic Pythium $\mathrm{sp}$. in response to another crop (biodiversity) and the increase in microbial activity in soil, observed by Mazzola and Gu (2000) in replant soil from apple orchards, may be further enhanced by the fungitoxic effect on Pythium of compounds released by GL-containing plants.

\section{Literature Cited}

Adams, P.B. 1971. Effect of soil temperature and soil amendments on Thielaviopsis root rot of sesame. Phytopathology 61:93-97.

Anderson, J.P.E. and K.H. Domsch. 1975. Measurement of bacterial and fungal contributions to respiration of selected agricultural and forest soils. Can. J. Microbiol. 21:314-322.

Chan, M.K.Y. and R.C. Close. 1987. Aphanomices root rot of peas. 3. Control by the use of cruciferous amendments. N.Z. Agr. Res. 30:225-233.

Charron, C.S. and C.E. Sams. 1999. Inhibition of Pythium ultimum and Rhizoctonia solani by shredded leaves of Brassica species. J. Amer. Soc. Hort. Sci. 125:462-467.

Chen, Y., H.A.J. Hoitink, A.F. Schmittehnner, and O.H. Tuovinen. 1988. The role of microbial activity in suppression of dumping off caused by Pythium ultimum. Phytopathology 78:314-322.

Cook, R.J., J.W. Sitton, and J.T. Walder. 1980. Evidence for Pythium as a pathogen of directdrilled wheat in the pacific Northwest. Plant Dis. 64:102-103

Davis, R.M. and J.J. Nunez. 1999. Influence of crop rotation on the incidence of Pythium-and Rhizoctonia-induced carrot root dieback. Plant Dis. 83:146-148.

Dhiangra, O.D. and J.B. Sinclair. 1986. Basic plant pathology methods, p. 179-189. CRC, Boca Raton, Fla.

Elmer, W.H. and J.A. LaMondia. 1999. Influence of ammonium sulphate and rotation on strawberry back root rot. Plant Dis. 83:119-123.

Gamliel, A. and J.J. Stapleton. 1993. Characterization of antifungal volatile compounds evolved from solarized soil amended with cabbage residues. Phytopathology 83:899-905.

Grünwald, N.J., S. Hu, and A.H.C. van Bruggen. 2000. Short-term cover crop decomposition in organic and conventional soils: Characterization of soil $\mathrm{C}, \mathrm{N}$, microbial and plant pathogen dynamics. Eur. J. Plant Pathol. 106:37-50.

Jeffers, S. and S.B. Martin. 1986. Comparison of two selective media for Phytophthora and Pythium species. Plant Dis. 70:1038-1043.

Lazzeri, L., L.M. Manici, G. Baruzzi, L. Malaguti, E. DePaoli, and L. Antoniacci. 1999. Primi risultati sull'azione dei sovesci di piante biocide nella coltivazione della fragola. Rivista di Frutticoltura 6:20-26.

Lazzeri, L., L.M. Manici, O. Leoni, and S. Palmieri. 2000. Soilborne phytopathogenic fungi control by Cleome hassleriana green manure. Acta Hort. 513:53-57.

Lynch, J.M. and L.M. Panting. 1980. Cultivation and the soil biomass. Soil Biol. Biochem. 12:2933.

Manici, L.M., L. Lazzeri, O. Leoni, G. Baruzzi, S. Galletti, and S. Palmieri. 2000. Suppressive activity of some glucosinolate enzyme degradation products on Pythium irregulare and Rhizoctonia solani. Pest Mgt. Sci. 56:921-926.

Manici, L.M., L. Lazzeri, and S. Palmieri. 1997. In vitro fungitoxic activity of some glucosinolates and their enzyme-derived products toward plant pathogenic fungi. J. Agr. Food Chem. 45:27682773.

Manici, L.M., O. Leoni, L. Lazzeri, S. Galletti, and S. Palmieri. 1999. Fungitoxic activity of four thio-functionalized glucosinolate enzyme derived products on ten soilborne pathogens. Pest. Sci. 55:486-488.

Mari, M., R. Iori, O. Leoni, and A. Marchi. 1993. In vitro activity of glucosinolate derived isothiocyanates against post-harvest fruit pathogens. Ann. Appl. Biol. 123:155-164.

Mayton, H.S., C. Olivier, S.F. Vaughn, and R. Loria. 1996. Correlation of fungicidal activity of Bras- 
sica species with allyl isothiocyanates production in macerated leaf tissue. Phytopathology 86:267-271.

Mazzola, M. 1998. Elucidation of the microbial complex having a causal role in the development of apple replant disease in Washington. Phytopathology 88:930-938.

Mazzola, M. and Y-H Gu. 2000. Impact of weath cultivation on microbial communities from replant soil and apple growth in greenhouse trials. Phytopathology 90:114-119.

Mazzola, M. 2000. Phyto-management of microbial community structure to enhance growth of apple in replant soil. Phytopathology 90:S102. Publ. N. P-2000-0076-SSA.

Muehlchen, A.M., R.E. Rand, and J.L. Parke. 1990 Evaluation of crucifer green manure for controlling Aphanomices root rot of peas. Plant Dis. 74:651-654.

Nelson, P.E., T.A. Tousson, W.F.O. Marasas. 1983. Fusarium species. An illustrate manual for identification. Pennsylvania State Univ. Press.

Official Journal of European Community Regulation. 1990. EEC 1864/90, June Enclosure VIII J.O. n.L170, 1990 27-34.

Ploetz, R.C., D.J. Mitchell, and R.N. Gallaher. 1985. Population dynamics of soilborne fungi in a field multi-cropped to rye and soybeans under reduced tillage in Florida. Phytopathology 75:1447-1451.

Ramirez-Villapudua, J. and D.E. Munnecke. 1988. Effect of solar heating and soil amendments of cruciferous residues on Fusarium oxysporum f.sp. conglutinans and other organisms. Phytopathology 78:289-295.

Rosa, E.A.S., R.K. Heaney, G.R. Fenwich, and C.A.M. Portas. 1997. Glucosinolates in crop plants. Hort. Rev. 19:99-215.

Samson, R.A. and E.S. van Reenen-Hoekstra. 1988. Introduction to food-borne pathogens. 3th ed Centraalbureau vor Schimmelcultures.

Sang, J.P., P.K. Minchinton, P.K. Johnstone, and J.W. Truscott. 1984. Glucosinolates profiles in the seed, root and leaf tissue of cabbage, mustard, rapeseed, radish and swede. Can. J. Plant Sci. 64:77-93.

Smolinska, U. and M. Horbowicz. 1999. Fungicidal activity of volatiles from selected cruciferous plants against resting propagules of soilborne pathogens. J. Phytopath. 147:119-124.

Smolinska, U., M.J. Morra, G.R. Knudsen, and P.D Brown. 1997. Toxicity of glucosinolate degradation products from Brassica napus seed meal toward Aphanomyces euteiches f. sp. pisi. Phytopathology 87:76-82

Stanghellini, M.E. and J.C. Hancock. 1971. Radial extend of the bean spermosphere and its relation to the behaviour of Pythium ultimum. Phytopathology 61:165-18.

Subbarao, K.V. and J.C. Hubbard. 1996. Interactive effect of broccoli residues and temperature on Verticillium dahliae microsclerotia in the soil and wilt in cauliflower. Phytopathology 86:1303-1310.
Sutton B.C. 1980. The Coelomycetes. CAB, Kew, Surrey, England.

United Nations Environment Programme. 1992. Montreal protocol assessment. Methyl bromide: Its atmospheric science, technology and economics. Synthesis report of the methyl bromide interim scientific assessment and methyl bromide interim technology and economic assessment.

Visentin, M., A. Tava, R. Iori, and S. Palmieri. 1992. Isolation and identification of trans-4methylthio-3-butenyl glucosinolate from radish roots (Raphanus sativus L.). J. Agr. Food Chem. 40:1687-1691.

Walker, J.C., S. Moreil, and H.H. Foster. 1937. Toxicity of mustard oils and related sulphur compounds to certain fungi. Amer. J. Bot. 24:536-541.

Watanabe, T., K. Hashimoto, and M. Sato. 1977. Pythium species associated with the strawberry roots in Japan, and their role in the strawberry stunt disease. Phytopathology 67:1324-1332.

Waterhouse, G.M. 1967. Key to Pythium Pringsheim. Mycol. Papers, no. 109. CAB, Kew, Surrey, England.

Waterhouse, G.M. 1968. The genus of Pythium Pringsheim. Mycol. papers, no 110. CAB, Kew, Surrey, England.

Waterhouse, G.M. and J.M. Waterston. 1966. Pythium deliense. C.M.I description of pathogenic fungi and bacteria, no. 116. CAB, Kew, Surrey, England. 